Volume 1 Nomor 2, Agustus 2016, halaman 103-112

\title{
PENGARUH MODEL PEMBELAJARAN CREATIVE PROBLEM SOLVING (CPS) TERHADAP KEMAMPUAN PENALARAN ADAPTIF MATEMATIS SISWA
}

\author{
Dian Nopitasari \\ Universitas Muhammadiyah Tangerang, d_novietasari@yahoo.com
}

\begin{abstract}
ABSTRAK
Penelitian ini dilakukan di salah satu SMP Negeri di Tangerang tahun ajaran 2015/2016, bertujuan untuk menganalisis pengaruh model pembelajaran CPS terhadap kemampuan penalaran adaptif matematis siswa. Metode yang digunakan dalam penelitian ini adalah metode kuasi eksperimen dengan desain penelitian randomized posttest only control group design. Sampel penelitian diperoleh sebanyak dua kelas dengan teknik Cluster Random Sampling. Berdasarkan hasil pengujian hipotesis menunjukkan bahwa kemampuan penalaran adaptif matematis dengan model pembelajaran Creative Problem Solving lebih tinggi dibandingkan kemampuan penalaran adaptif matematis siswa yang diajar dengan model pembelajaran konvensional.

Kata Kunci: Creative Problem Solving, Penalaran Adaptif Matematis, Induktif Intuitif, Deduktif Intuitif.
\end{abstract}

\begin{abstract}
This research was conducted in one of junior high school in Tangerang academic year 2015/2016. Aimed to analyze the effect of CPS model on the students' mathematical adaptive reasoning skills. The method used in this study was a quasi experimental method with randomized posttest only control group design. Samples were obtained as many as two classes by cluster random sampling technique. Based on result of hypothesis this show that students' mathematical adaptive reasoning skills who were taught by creative problem solving model was higher than the students'mathematical adaptive reasoning skills of those who were taught by conventional model

Keywords: Creative Problem Solving Model, Mathematical adaptive reasoning, Inductive intuitive, Deductive intuitive.
\end{abstract}

How to Cite: Nopitasari, D. (2016). Pengaruh Model Pembelajaran Creative Problem Solving (CPS) Terhadap Kemampuan Penalaran Adaptif Matematis Siswa. Mathline: Jurnal Matematika dan Pendidikan Matematika, Vol.1, No.2, 103-112.

\section{PENDAHULUAN}

Pendidikan merupakan aspek penting bagi perkembangan ilmu pengetahuan dan teknologi. Hal tersebut dikarenakan pendidikan mempunyai tugas menyiapkan sumber daya 
manusia yang mampu menghadapi segala macam tuntutan zaman. Melalui pendidikan, potensi yang ada didalam diri seseorang dikelola dan dikembangkan. Disinilah seseorang akan belajar dan mendapatkan pembelajaran serta pengalaman yang berguna tidak hanya bagi dirinya sendiri, melainkan untuk masa depan bangsa juga.

Salah satu bidang studi yang mendukung perkembangan ilmu pengetahuan dan teknologi adalah matematika. Itu sebabnya matematika menjadi bidang studi wajib mulai dari jenjang Sekolah Dasar (SD) sampai Sekolah Menengah Atas (SMA), bahkan sampai Perguruan Tinggi. Fakta lainnya, bidang studi matematika memiliki proporsi waktu yang lebih banyak dibandingkan bidang studi lainnya. Hal tersebut menunjukkan bahwa matematika memang diharapkan dapat mengembangkan kemampuan dan potensi seseorang secara maksimal.

Hayat \& Yusuf (2010) menyatakan bahwa, kemampuan bernalar atau reasoning merupakan satu kompetensi yang paling utama dibutuhkan saat sekarang dan di masa depan dalam pembelajaran matematika. Terlebih lagi matematika memiliki salah satu ciri khusus yaitu sifatnya yang menekankan pada proses deduktif yang memerlukan penalaran logis dan aksiomatik. Secara khusus dalam matematika siswa harus memahami bahwa penalaran baik induktif, deduktif dan intuitif memainkan peranan yang sangat penting. Siswa perlu menyadari bahwa kemampuan tingkat tinggi dalam matematika selain membutuhkan penalaran induktif dan deduktif juga memerlukan intuisi sebagai dasarnya.

Berdasarkan beberapa pendapat di atas, dapat ditarik sebuah kesimpulan bahwa bernalar serta kemampuan intuitif merupakan aspek yang sangat penting dalam matematika. Kemampuan bernalar dan kemampuan intuitif dijadikan modal untuk memahami konsepkonsep matematika dengan benar dan masuk akal baik melalui menduga ataupun melakukan pembuktian. Perlu disadari perkembangan zaman mengharuskan kita untuk berkembang dalam proses berpikir. Kita harus memiliki kemampuan tingkat tinggi untuk mampu mengimbangi perkembangan zaman. Kemampuan bernalar dan kemampuan intuitif inilah dua aspek kemampuan tingkat tinggi yang perlu dimiliki siswa guna mempersiapkan mereka di masa depan.

Selama pembelajaran matematika, dalam mempelajari konsep-konsep, siswa tidak terlepas dari suatu permasalahan matematis yang membutuhkan sebuah solusi. Ketika mempelajari konsep dan menyelesaikan suatu permasalahan, siswa memiliki kebebasan akan memberikan solusi secara analisis menggunakan langkah-langkah yang jelas berdasarkan 
logika atau dapat pula menyelesaikan masalah tersebut secara intuitif yaitu, memberikan solusi secara spontan, cepat tetapi tepat. Dengan kata lain, ada siswa pada saat menyelesaikan masalah matematis telah mengetahui atau menemukan solusinya sebelum siswa tersebut menuliskan langkah-langkah dalam menemukan solusi.

Kemampuan intuitif dan bernalar keduanya terdapat didalam penalaran adaptif, yaitu kemampuan yang menghubungkan konsep dan situasi melalui penalaran induktif intuitif dan deduktif intuitif. Dalam prosesnya siswa harus mampu memberikan solusi dari permasalahan matematis menggunakan kemampuan intuitifnya untuk kemudian solusi tersebut dibuktikan dan diperkuat menggunakan langkah-langkah secara analisis atau melakukan justifikasi.

Melihat pemaparan sebelumnya mengenai betapa pentingnya kemampuan intuitif dan bernalar dapat disimpulkan bahwa penalaran adaptif merupakan bagian yang diperlukan untuk menunjang keberhasilan di dalam proses pembelajaran matematika yang harus terus dilatih dan dikembangkan agar pembelajaran matematika menjadi lebih bermakna dan mencapai tujuan pembelajaran yang diharapkan. Melalui penalaran adaptif, siswa akan mampu menyelesaikan permasalahan secara cepat, tepat dan siswa akan membangun pikirannya untuk menguasai konsep matematika secara utuh baik untuk sekarang, nanti dan menjadi landasan siswa dalam bertindak secara logis dalam kegiatan bermatematika ataupun dalam aktivitas sehari-hari lainnya.

Pada kenyataannya di satu sisi penalaran adaptif sangat penting untuk dimiliki dan dikembangkan akan tetapi di sisi lain ternyata kemampuan penalaran adaptif siswa masih rendah. Hal ini dapat dilihat dari hasil tes pra penelitian yang peneliti lakukan terhadap siswa di salah satu SMP Negeri di Tangerang. Hasil tes tersebut menunjukkan bahwa umumnya kemampuan penalaran adaptif matematis siswa masih rendah. Hal tersebut terlihat dari 38 siswa, 25 siswa diantaranya masih mengalami kesulitan dalam menyelesaikan soal dengan kemampuan penalaran adaptif, hanya 3 siswa yang mampu menyelesaikan soal dengan baik pada aspek induktif intuitif dan deduktif intuitif. Dengan demikian hanya 34,21\% siswa yang mampu menyelesaikan soal dengan kemampuan penalaran adaptif. Berdasarkan analisis tersebut, ini menandakan bahwa sebenarnya siswa memiliki potensi untuk mengembangkan kemampuan penalaran adaptifnya. Hal ini tidak sepatutnya dibiarkan begitu saja. Diperlukan upaya untuk meningkatkan kearah yang lebih baik.

Untuk meningkatkan kemampuan penalaran adaptif matematis siswa diantaranya dengan memilih suatu model pembelajaran yang berdasarkan pada prinsip pemecahan 
masalah. Leeuw (Kurniawati, 2006) mengemukakan bahwa ketika seseorang belajar pemecahan masalah, pada intinya dia pun sedang belajar berpikir (learning to think) dan belajar bernalar (learning to reason) untuk mengaplikasikan pengetahuan-pengetahuan yang telah diperoleh untuk memecahkan masalah yang belum pernah dijumpai. Selain itu Joakim Samuelsson mengatakan bahwa "Teaching methods where students are able to use their language in order to discuss mathematical problem seems to have positive effect on student conceptual understanding, strategic competence, and adaptive reasoning". Uraian tersebut menjelaskan bahwa pembelajaran pemecahan masalah dapat dijadikan alternatif untuk melatih penalaran adaptif matematis siswa dalam memahami matematika secara utuh. Terlebih lagi dalam kehidupan sehari-hari siswa tidak terlepas dari masalah-masalah baik matematika atau non matematika yang perlu diselesaikan.

Model pembelajaran Creative Problem Solving (CPS) adalah suatu model pembelajaran pemecahan masalah yang menekankan penemuan berbagai alternatif ide atau gagasan untuk mencari penyelesaian berupa solusi yang paling efisien dari suatu permasalahan menggunakan proses berpikir divergen dan konvergen. Proses berpikir divergen untuk menghasilkan banyak ide berdasarkan intuisi dalam menyelesaikan masalah, sedangkan berpikir konvergen berperan dalam pengambilan keputusan atas ide yang ada. Melalui berpikir divergen dalam model pembelajaran CPS melatih kemampuan intuitif siswa karena proses berpikir divergen ada berdasarkan intuisi, sedangkan proses berpikir konvergen dalam model pembelajaran CPS melatih kemampuan penalaran siswa. Kemampuan intuitif bisa terdapat dalam bagian apapun dalam kemampuan penalaran. Kemampuan intuitif, penalaran induktif dan deduktif ketiganya terdapat dalam penalaran adaptif. Hal tersebut juga terlihat dari langkah-langkah creative problem solving yang bertujuan menemukan solusi terbaik melalui fakta-fakta, konsep, prosedur. Tujuan tersebut erat kaitannya dengan penalaran adaptif matematis yang melihat segala sesuatu tepat dan masuk akal berdasarkan fakta, konsep, dan prosedur.

Model pembelajaran ini dirasa mampu mengembangkan dan melatih penalaran adaptif matematis siswa, karena pada model pembelajaran ini menekankan siswa untuk melatih dan mengembangkan kemampuan penalaran baik induktif dan deduktif yang melibatkan kemampuan intuitif. Dengan CPS, siswa dilatih untuk mengidentifikasi sebuah permasalahan tetapi tidak seperti metode pemecahan masalah pada umumnya, model ini lebih menekankan pada kebutuhan untuk menunda judgment terhadap gagasan-gagasan dan solusi- 
solusi yang diperoleh hingga ada keputusan final yang dibuat. Sehingga pada tahap-tahap tersebut sangat berpotensi sekali untuk melatih dan meningkatkan penalaran adaptif matematis siswa. Berbagai solusi yang potensial diterima karena yang dibutuhkan dalam brainstorming (pengungkapan pendapat) dalam CPS adalah kuantitas ide, bukan kualitas ide.

Berdasarkan uraian yang telah dipaparkan di atas, peneliti menyusun rumusan masalah yang akan menjadi fokus penelitian kali ini, yaitu bagaimana kemampuan penalaran adaptif matematis siswa yang diajar dengan model pembelajaran Creative Problem Solving (CPS), bagaimana kemampuan penalaran adaptif matematis siswa yang diajar dengan pembelajaran konvensional, apakah kemampuan penalaran adaptif matematis siswa yang diajar dengan model pembelajaran Creative Problem Solving (CPS) lebih tinggi dari siswa yang diajar dengan pembelajaran konvensional. Tujuan penelitian ini adalah mengetahui kemampuan penalaran adaptif matematis siswa yang diajar dengan model pembelajaran Creative Problem Solving (CPS), mengetahui kemampuan penalaran adaptif matematis siswa yang diajar dengan pembelajaran konvensional, membandingkan kemampuan penalaran adaptif matematis siswa antara yang diajar dengan model pembelajaran Creative Problem Solving (CPS) dengan siswa yang diajar dengan pembelajaran konvensional.

\section{METODE PENELITIAN}

Metode yang digunakan dalam penelitian ini adalah metode kuasi eksperimen dengan Randomized Post-test Only Control Group Design. Pengambilan sample dilakukan dengan teknik cluster random sampling, sehingga diperoleh kelas VIII C dan VIII E. Kelas VIII E sebagai kelas eskperimen berjumlah 38 siswa yang diterapkan model pembelajaran CPS dan kelas VIII C sebagai kelas kontrol berjumlah 38 siswa yang diterapkan pembelajaran konvensional yaitu eskpositori. Penelitian ini dilakukan 9 kali pertemuan pada kelas eksperimen dan kontrol. Delapan pertemuan untuk pembelajaran materi lingkaran dan satu pertemuan terakhir dilakukan posttest dengan instrumen yang sama yaitu 6 butir soal uraian kemampuan penalaran adaptif matematis. Adapun analisis yang digunakan adalah Independent samples T Test dengan menggunakan perangkan lunak SPSS.

\section{HASIL DAN PEMBAHASAN}

Berikut ini disajikan data hasil perhitungan tes kemampuan penalaran adaptif matematis siswa setelah pembelajaran dilaksanakan. 
Tabel 1. Deskriptif Hasil Tes Kemampuan Penalaran Adaptif Matematis Siswa

\begin{tabular}{ccc}
\hline \multirow{2}{*}{ Statistik Deskriptif } & \multicolumn{2}{c}{ Kelas } \\
\cline { 2 - 3 } & Eksperimen & Kontrol \\
\hline Jumlah Siswa & 38 & 38 \\
Skor Ideal & 24 & 24 \\
Maksimum (Xmaks) & 23 & 22 \\
Minimum (Xmin) & 16 & 10 \\
Rata-rata & 19,40 & 16,50 \\
Simpangan Baku (S) & 2,15 & 3,03 \\
\hline Dari Tabel 1 terlihat adanya perbedaan hasil perhitungan statistik deskriptif diantara
\end{tabular}
kelas eksperimen dan kelas kontrol. Skor tertinggi di kelas eksperimen lebih besar dibanding kelas kontrol dengan selisih 1, begitu pun dengan skor terendahnya. Skor terendah kelas eksperimen lebih besar 6 angka dibanding kelas kontrol. Artinya kemampuan penalaran adaptif matematis perorang tertinggi terdapat di kelompok eksperimen sedangkan kemampuan penalaran adaptif matematis perorang terendah terdapat di kelompok kontrol. Skor rata-rata dari 38 siswa di kelas eksperimen lebih tinggi dibandingkan dengan skor ratarata 38 siswa di kelas kontrol dengan selisih 2,9. Jika dilihat dari simpangan baku, simpangan baku kelas kontrol lebih besar daripada kelas eksperimen, ini menunjukkan bahwa sebaran pada kelas kontrol lebih heterogen. Artinya skor kemampuan penalaran adaptif matematis siswa di kelas kontrol lebih bervariasi dan menyebar terhadap rata-rata kelas, sedangkan kemampuan penalaran adaptif matematis pada kelas eksperimen lebih mengelompok.

Secara khusus, skor kemampuan penalaran adaptif matematis siswa baik pada kelas eksperimen dan kelas kontrol berdasarkan indikatornya masing-masing disajikan dalam Tabel 2 di bawah ini.

Tabel 2. Perbandingan Kemampuan Penalaran Adaptif Matematis Siswa Kelas Eksperimen dan Kelas Kontrol

\begin{tabular}{cccccccc}
\hline \multirow{2}{*}{ Indikator } & \multirow{2}{*}{ Skor Ideal } & \multicolumn{3}{c}{ Eksperimen } & \multicolumn{3}{c}{ Kontrol } \\
\cline { 3 - 8 } & & Skor Siswa & $\bar{x}$ & \% & Skor Siswa & $\bar{x}$ & \% \\
\hline Induktif Intuitif & 12 & 401 & 10.03 & 83.54 & 335 & 8.38 & 69.79 \\
Deduktif Intuitif & 12 & 375 & 9.38 & 78.13 & 325 & 8.13 & 67.71 \\
Keseluruhan & 24 & 776 & 19.40 & 80.83 & 660 & 16.50 & 68.75 \\
\hline
\end{tabular}

Persentase skor kemampuan penalaran adaptif matematis yang diperoleh kelas eksperimen lebih tinggi daripada kelas kontrol untuk setiap indikatornya, baik itu berupa kemampuan induktif intuitif maupun deduktif intuitif. Selisih pada kemampuan induktif intuitif pada kedua kelas yaitu sebesar $13,75 \%$, sedangkan pada kemampuan deduktif intuitif 
memiliki selisih 10,42\% pada kedua kelas. Persentase skor keseluruhan indikator penalaran adaptif matematis kelas eksperimen lebih tinggi 12,08\% daripada kelas kontrol.

Sebelum menguji kesamaan dua rata-rata kedua kelompok tersebut dengan menggunakan analisis Independent Samples $T$ Test, diperlukan uji normalitas dan homogenitas terlebih dahulu.

Tabel 3. Uji Normalitas Postes Kelas Eksperimen dan Kontrol

\begin{tabular}{lcc}
\hline & Eksperimen & Kontrol \\
\hline Chi-Square & $9.600^{\mathrm{a}}$ & $18.200^{\mathrm{b}}$ \\
Df & 7 & 11 \\
Asymp. Sig. & .212 & .077 \\
\hline
\end{tabular}

Hasil uji normalitas dengan analisis Chi-Square pada taraf signifikan $\alpha=0,05$ menunjukkan data skor hasil posttest kemampuan penalaran adaptif matematis siswa kelas eksperimen dan kontrol berdistribusi normal, hal ini didapat dengan membandingkan nilai signifikan hasil perhitungan dengan $\alpha$ yang telah ditetapkan. Nilai signifikan skor kemampuan penalaran adaptif matematis siswa pada kedua kelas tersebut (eksperimen = 0,212 dan kontrol $=0,077$ ) lebih besar daripada harga $\alpha=0,05$.

Tabel 4. Hasil Uji Kesamaan Dua Rata-rata Kemampuan Penalaran Adaptif Kelas Eksperimen dan Kontrol

\begin{tabular}{lcccccc}
\hline & \multicolumn{2}{c}{$\begin{array}{c}\text { Levene's Test for Equality of } \\
\text { Variances }\end{array}$} & \multicolumn{3}{c}{ t-test for Equality of Means } \\
\cline { 2 - 7 } & F & Sig. & t & Df & $\begin{array}{c}\text { Sig. (2- } \\
\text { tailed) }\end{array}$ \\
\hline $\begin{array}{l}\text { Equal } \\
\text { assumed }\end{array}$ & variances & 3.246 & 0.075 & 4.940 & 78 & .000 \\
\hline
\end{tabular}

Hasil uji homogenitas menggunakan uji Levene, pada taraf signifikan $\alpha=0,05$ menunjukkan data skor hasil posttest kemampuan penalaran adaptif matematis siswa kelas eksperimen dan kelas kontrol adalah homogen, hal ini didapat dengan membandingkan nilai signifikansi hasil perhitungan dengan $\alpha$ yang telah ditetapkan. Nilai signifikansi yang tertera pada hasil pengujian homogenitas tersebut (signifikansi $=0,075$ ) lebih besar daripada harga $\alpha$ $=0,05$. Hasil uji homogenitas juga bisa dilihat pada output analisis Independent Samples $T$ Test di atas.

Pengujian normalitas dan homogenitas telah menunjukkan bahwa skor posttest kemampuan penalaran adaptif matematis pada kedua kelompok berdistribusi normal dan 
varian kedua kelompok juga sama atau homogen, oleh karena itu pengujian kesamaan dua rata-rata dapat dilakukan dengan menggunakan analisis Independent Samples T Test. Hasil uji kesamaan dua rata-rata posttest kelas eksperimen dan kontrol untuk kemampuan penalaran adaptif matematis menunjukkan untuk menerima $\mathrm{H}_{1}$ dan menolak $\mathrm{H}_{0} . \mathrm{H}_{1}$ menyatakan bahwa rata-rata kemampuan penalaran adaptif matematis siswa yang pembelajarannya menggunakan model pembelajaran Creative Problem Solving (CPS) lebih tinggi daripada siswa yang menggunakan pembelajaran ekspositori pada taraf kepercayaan 95\%. Hal ini dapat diidentifikasi dari nilai signifikansi perhitungan (signifikansi=0.000) pada tabel 4 yang bernilai kurang dari nilai $\alpha=0,05$.

Hasil penelitian menunjukkan bahwa kemampuan penalaran adaptif matematis siswa setelah diajarkan melalui model pembelajaran Creative Problem Solving (CPS) secara signifikan lebih baik daripada yang diajarkan melalui pembelajaran secara konvensional yaitu pembelajaran ekspositori. Skor rata-rata kemampuan penalaran adaptif matematis siswa melalui model pembelajaran CPS secara signifikan juga lebih tinggi daripada melalui pembelajaran konvensional. Hal ini terjadi karena model pembelajaran Creative Problem Solving (CPS) mendorong siswa untuk mampu memecahkan permasalah matematis yang menekankan penemuan berbagai alternatif ide atau gagasan melibatkan proes berpikir divergen dan konvergen untuk mencari penyelesaian berupa solusi yang paling efisien dari suatu permasalahan. Berbeda dengan pembelajaran konvensional yaitu pembelajaran ekspositori, dimana pembelajarannya masih berpusat pada guru, sehingga siswa kurang memiliki kesempatan untuk menggunakan dan melatih kemampuan penalaran adaptif matematis untuk ide-ide yang mereka miliki.

Seperti yang telah disampaikan sebelumnya, model pembelajaran CPS terdiri dari lima tahapan pembelajaran yaitu, menemukan fakta, menemukan masalah, menemukan ide, menemukan solusi, dan menemukan penerimaan. Tahapan-tahapan pada model pembelajaran CPS mampu melatih dan mengembangkan kemampuan penalaran adaptif matematis siswa. Dalam prosesnya pada setiap tahapan CPS melibatkan proses berpikir divergen yang mampu melatih kemampuan intuitif, sedangkan proses berpikir konvergen melatih kemampuan penalaran induktif dan deduktif, sehingga dapat disimpulkan bahwa kemampuan penalaran adaptif dapat ditingkatkan melalui model pembelajaran CPS yang melibatkan proses berpikir divergen dan konvergen. Dapat disimpulkan bahwa model pembelajaran CPS dapat mengembangkan kemampuan penalaran adaptif siswa. 
Kemampuan penalaran adaptif matematis siswa yang diterapkan model pembelajaran Creative Problem Solving (CPS) lebih tinggi daripada siswa yang diterapkan pembelajaran secara konvensional dengan menggunakan pembelajaran ekspositori. Hal ini sejalan dengan pendapat Pehkonen yang menyatakan bahwa berpikir kreatif merupakan kombinasi antara berpikir divergen yang berdasarkan intuisi dan berpikir logis. Aspek kreatif tersebut dibutuhkan dalam model pembelajaran Creative Problem Solving (CPS) sehingga pada model ini melatih siswa untuk berpikir divergen yang berdasarkan intuisi dan berpikir logis atau konvergen. Berpikir divergen berdasarkan intuisi dan logis keduanya terdapat di dalam kemampuan penalaran adaptif matematis siswa, sehingga dapat disimpulkan bahwa model pembelajaran Creative Problem Solving (CPS) dapat melatih dan mengembangkan kemampuan penalaran adaptif siswa.

Hasil penelitian ini juga sejalan dengan hasil penelitian Desriyanti (2014) berkaitan dengan pengaruh model pembelajaran Thinking Aloud Pair Problem Solving (TAPPS) terhadap kemampuan penalaran adaptif matematis siswa dengan nilai rata-rata 63,80, memberikan kesimpulan bahwa model pembelajaran TAPPS efektif untuk meningkatkan kemampuan penalaran adaptif matematis siswa. Akan tetapi kemampuan penalaran adaptif yang diterapkan model pembelajaran Creative Problem Solving (CPS) memiliki nilai rata-rata yang lebih tinggi daripada kemampuan penalaran adaptif yang diterapkan model pembelajaran TAPPS yaitu sebesar 80,83, sehingga dapat disimpulkan bahwa model pembelajaran CPS lebih efektif untuk meningkatkan kemampuan penalaran adaptif matematis siswa.

\section{KESIMPULAN}

Berdasarkan hasil analisis dan pembahasan, maka dalam penelitian mengenai pembelajaran Creative Problem Solving terhadap kemampuan penalaran adaptif matematis siswa diperoleh beberapa kesimpulan sebagai berikut:

1. Kemampuan penalaran adaptif matematis siswa yang diterapkan model pembelajaran Creative Problem Solving memiliki tingkat indikator yang paling baik pada kemampuan menduga dan menarik kesimpulan umum berdasarkan sejumlah data yang teramati (induktif intuitif). Akan tetapi kemampuan menduga dan menarik kesimpulan logis (deduktif intuitif) hanya sedikit saja selisihnya dengan kemampuan induktif intuitif, bahkan hampir seimbang. Dapat dikatakan bahwa model pembelajaran Creative Problem 
Solving merupakan pembelajaran yang efektif untuk mengembangkan kemampuan penalaran adaptif matematis siswa pada aspek induktif intuitif dan deduktif intuitif.

2. Kemampuan penalaran adaptif matematis siswa yang diterapkan pembelajaran secara konvensional memiliki tingkat indikator yang paling baik pada aspek induktif intuitif dibandingkan pada aspek deduktif intuitif. Pada kedua aspek tersebut juga memiliki selisih yang tidak jauh. Siswa yang diberi pembelajaran secara konvensional memiliki kemampuan deduktif intuitif yang hampir seimbang dengan kemampuan induktif intuitif, meskipun kemampuan induktif intuitif yang lebih besar. Secara keseluruhan, siswa yang diajar dengan model pembelajaran konvensional memiliki kemampuan penalaran adaptif matematis yang seimbang pada kedua aspek, namun cukup rendah. Dapat dikatakan bahwa model pembelajaran konvensional belum cukup efektif untuk mengembangkan kemampuan penalaran adaptif matematis siswa.

3. Kemampuan penalaran adaptif matematis siswa yang diterapkan model pembelajaran Creative Problem Solving lebih tinggi dibandingkan kemampuan penalaran adaptif matematis siswa yang diterapkan model pembelajaran secara konvensional. Baik aspek induktif intuitif dan deduktif intuitif pada siswa yang diterapkan model CPS memiliki keunggulan jika dibandingkan siswa yang diterapkan model pembelajaran secara konvensional. Perbedaan pada setiap indikator pada kedua kelas tersebut sangat terlihat. Dengan demikian, model pembelajaran Creative Problem Solving lebih baik daripada model pembelajaran konvensional dalam mengembangkan kemampuan penalaran adaptif matematis.

\section{DAFTAR PUSTAKA}

Desriyanti, Y. (2014). Pengaruh Metode Pembelajaran Thinking Aloud Pair Problem Solving (TAPPS) Terhadap Kemampuan Penalaran Adaptif Matematis Siswa. Skripsi Universitas Islam Negeri Jakarta: Tidak diterbitkan.

Hayat, B \& Yusuf, F. (2010). Benchmark Internasional Mutu Pendidikan. Jakarta: PT Bumi Aksara.

Kurniawati, L. (2006). Pembelajaran dengan Pendekatan Pemecahan Masalah untuk Meningkatkan Kemampuan Pemahaman dan Penalaran Matematik Siswa SMP. Jurnal ALGORITMA, Vol 1 No. 1 p.77.

Samuelsson, J. (2010). The Impact of The Approaches on Student Mathematical Profiency in Sweden. International Electronic Journal of Mathematics Education, Vol 5 No. 2 p.61. 